\title{
Strategi Penerapan Kebijakan Sovereign Wealth Funds (SWFs) di Indonesia: Studi Literatur dan Studi Komparatif Oman
}

\author{
Eko Eddya Supriyanto \\ STKIP NU Kabupaten Tegal, Indonesia, email: ekoeddya@stkipnutegal.ac.id
}

\section{Info Artikel}

Submit: 09 Jul 2020

Accepted: 23 Jan 2021

Publish: 16 Feb 2021

Keywords:

Sovereign Wealth Funds

(SWFs); Economic Policy;

Comparative Studies

\section{Kata Kunci:}

Sovereign Wealth Funds

(SWFs); Kebijakan

Ekonomi; Studi Komparasi

\section{(cc) EY-SA}

Lisensi: cc-by-sa

\begin{abstract}
The application of Sovereign Wealth Funds (SWFs) in monetary policy is a solution to the counter-globalist policies that have so far prevented developing countries from being able to move into developed countries. The State of Oman is an inspiration for the kingdom of Saudi Arabia in the policy of Sovereign Wealth Funds (SWFs) which change the direction of state policy on hospitality services for pilgrims Umroh and Hajj. The oman state also has been a country that focuses its main income on petroleum to calculate all its petroleum assets which are then sold in the form of Sovereign Wealth Funds (SWFs) to change the country's policy on tourism hospitality activities. This research will explain SWFs in terms of definition, history and concept, then we will see the application of SWFs in oman countries that have been going on since 2010. The implementation strategy of SWFs in Indonesia certainly requires courage from the Indonesian government because the presence of rare mineral content in this country is certainly very needed for high-tech materials in developed countries in the world. Indonesia is very likely to implement SWFs and can become developed countries with a model of applying SWFs on rare earth minerals owned by Indonesia, which are entirely in this country.
\end{abstract}

\begin{abstract}
Abstrak
Penerapan kebijakan Sovereign Wealth Funds (SWFs) dalam kebijakan moneter merupakan solusi dari kebijakan kontra globalis yang selama ini menghambat negara-negara berkembang untuk dapat melangkah menjadi negara maju. Negara Oman menjadi inspirasi bagi kerajaan Arab Saudi dalam kebijakan Sovereign Wealth Funds (SWFs) yang merubah arah kebijakan negara pada kegiatan hospitality pelayanan jamaah umroh dan jamaah haji. Negara oman juga yang selama ini menjadi negara yang menitik beratkan pendapatan utamanya pada minyak bumi melakukan penghitungan seluruh asset minyak buminya yang kemudian dijual dalam bentuk Sovereign Wealth Funds (SWFs) untuk merubah kebijakan negaranya pada kegiatan hospitality pariwisata. Penelitian menjelaskan SWFs secara definisi, sejarah dan konsep penerapan SWFs di Negara Oman yang sudah berlangsung sejak tahun 2010. Starategi penerapan SWFs di Indonesia tentu perlu keberanian dari pemerintah Indonesia karena keberadaan kandungan mineral jarang yang dimiliki negara ini tentu sangat dibutuhkan untuk bahan teknologi tingkat tinggi negara-negara maju di dunia. Indonesia sangat mungkin menerapkan SWFs dan bisa menjadi negara maju dengan model penerapan SWFs pada mineral tanah jarang yang dimiliki oleh Indonesia yang seluruhnya ada di Negeri ini.
\end{abstract}




\section{PENDAHULUAN}

Arus globalisasi mengharuskan arus global supply chain ditentukan oleh segelintir orang, bahkan setiap barang yang masuk ataupun keluar harus atas sepengetahuan kelompok globalis ini. Ini menjadikan negara-negara berkembang susah untuk memenuhi kebutuhannya sendiri. Oleh sebab itu, berlaku teori ketergantung negara-negara berkembang kepada negara adikuasa pemegang kendali kekuasaan dunia.

Belum lagi dengan berkembangnya revolusi industry 4.0 dan society 5.0 yang semua model bisnis mengharuskan menggunakan big data, Internet of Things (IoT), Artificial intelligent (AI), dan arus teknologi tinggi secara massif. Ketentuan tersebut membuat negara-negara dunia ketiga akan bergantung kepada negara-negara maju yang mempunyai teknologi tinggi tersebut. Dalam kaitannya dengan pendanaan belanja negara, negaranegara dunia ketiga yang biasanya mempunyai sumber daya alam yang memadai namun karena keterbatasannya dalam mengelola kekayaan alam tersebut akhirnya di swakelolakan kepada negara lain yang mampu mengolah kekayaan alam atau mineral tersebut.

SWF merupakan nama yang cukup baru untuk sesuatu yang sudah ada cukup lama yang mana aset dipegang oleh pemerintah dalam bentuk mata uang negara lain. Semua negara memiliki cadangan devisa (biasanya dalam dolar, euro, atau yen). Ketika suatu negara, dengan menjalankan surplus neraca berjalan, mengakumulasi lebih banyak cadangan daripada yang dibutuhkannya untuk tujuan segera, ia dapat menciptakan dana pemerintah untuk mengelola sumber daya "ekstra" tersebut.

Jika melihat pernyataan dari beberapa eksekutif IMF maupun World Bank, mereka melakukan counter terhadap negara-negara debiturnya agar tidak menerapkan konsep $S W F$ ini. Karena Ketika negara-negara nasabah IMF menerapkan SWFs maka negara-negara tersebut akan meninggalkan IMF karena mereka telah mempunyai sumber dana untuk membangun diri mereka. Sebagaimana dalam artikel Simon Johnson seorang Direktur Departemen Penelitian IMF yang juga merupakan Konselor Ekonomi di Amerika Serikat, beliau mengungkapkan bahwa $S W F$ dapat berkontribusi pada ledakan global yang Panjang dari segi produktivitas yang tentu pertumbuhannya sangat cepat di seluruh dunia, dan ini akan menjadi krisis bagi negara-negara yang tidak mempunyai sumber daya alam yang asetnya dikelola dalam bentuk $S W F$.

Tujuan paper adalah meninjau secara literatur yang ada terkait dengan akar Sovereign Wealth Funds untuk memahami model pendanaan ini secara rinci. Untuk menemukan informasi mengenai pertanyaan penelitian utama, komponen utama, dan karakteristik $S W F$. pada fase ini juga memberikan analisis sejarah, pertumbuhan, peran, strategi investasi, peraturan $S W F$, standar operasi, tren saat ini dan debat tentang dampak keuangan global dari adanya teori $S W F$ ini. Analisis dari setiap aspek yang berbeda tentang $S W F$ memungkinkan seseorang untuk mengidentifikasi factor-faktor yang mempengaruhi $S W F$. Masalah saat ini yang menjadi perhatian dunia di media adalah tata Kelola, transparansi, akuntabilitas, motif investasi yang dibahas dalam domain penilaian SWF. Tentu ini harus juga mengidentifikasi isu-isu utama dalam trens global tentang $S W F$ seperti pengaruhnya terhadap ekonomi, pembangunan regional, dan dampaknya terhadap pasar keuangan global serta perdagangan internasional. Analisis literatur yang reflektif dan kritis seperti itu, akan memberikan pandangan komprehensif tentang $S W F$ dan sistem manajemennya.

Mengikuti Sovereign Wealth Funds secara definisi tentu memerlukan perspektif yang berbeda tentang asal dari model pendanaan ini. Tujuan, sumber uang dan tujuan utama mereka atau tujuan memulai dana kekayaan. (Kotter \& Lel, 2011) berpendapat bahwa SWF dapat didefinisikan sebagai langkah investasi milik pemerintah tanpa 
kewajiban eksplisit kepada pemiliknya selain dari dalam negeri kepada pemerintah, paparan secara signifikan terhadap asset asing berisiko tinggi dan cakrawala investasi jangka panjang. Sedangkan (Dewenter et al., 2010) mendefinisikan bahwa SWF merupakan kendaraan invetasi yang mengelola portfolio atas nama pemerintah mereka dan modal investasi mereka biasanya berasal dari pendapatan minyak bumi seperti dana wilayah GCC, Russia atau Norwegia, dapat juga berupa transaksi berjalan yang persisten seperti di negara Tiongkok atau Singapura.

Definisi-definisi tersebut menjelaskan sumber-sumber cadangan input untuk sovereign wealth funds dan pemanfaatan dana input tersebut ke dalam investasi. Bagian tersebut menjelaskan sejarah pengembangan konseptual SWF yang memungkinkan seseorang untuk memahami hubungan teoritis $S W F$ dan akar yang ada.

Tujuan utama dari pendanaan model ini adalah untuk meningkatkan likuiditas dalam sistem ekonomi sekalian memantau proses untuk meningkatkan profitabilitas dan basis asset sebagaiman diatur oleh peraturan masing-masing pemerintah atau kementerian yang mengelola dana tersebut. Jika kita menyimpulkan makna dasar $S W F$ dari namanya maka terdapat komponen "Sovereign" yang berarti penguasa atau menambah arti strategis dan kepemilikan negara pada dana ini, pada kata "wealth" dalam istilah $S W F$ dikatakan lebih terkait dengan penciptaan dan pemeliharaan asset keuangan yang berbeda, misalnya saham ekuitas, obligasi, properti, logam mulia, dan instrument keuangan lainnya. Jika membahasnya secara umum, $S W F$ dapat didefinisikan sebagai asset dan dana investasi yang dimiliki dan dikelola oleh pemerintah. Sumber dana aliran masuk untuk SWF adalah cadangan devisa, ekspor komoditas, hasil privatisasi, atau surplus akun fiscal. Terlepas dari penciptaan kekayaan tersebut, $S W F$ memiliki tujuan utama yaitu stabilisasi mata uang (Currency), peningkatan perdagangan bilateral, atau control ekonomi dalam negari seperti harga komoditas dan inflasi (Mahajan et al., 2008). Itu tidak mungkin menganggap mereka homogen sesuai dengan karakteristik karena sumber dana mereka, struktur tata Kelola, pola investasi, tujuan dan manajemen operasi sangat jauh berbeda. Sebagai contohnya adalah dana pension pemerintah negara Norwegia tidak memisahkan badan hukum dari bank sentral negara sebagaimana Korea membentuk badan hukum lain untuk penglolaan investasi dari Pemerintah Korea (Bernstein et al., 2013).

Tabel 1. Berbagai Sumber dan Tujuan SWF

\begin{tabular}{|c|c|c|c|}
\hline Tujuan Sumber & Komoditas/pendapatan & Tujuan Fiskal & Cadangan Devisa \\
\hline $\begin{array}{l}\text { Stabilisasi aliran } \\
\text { pendapatan } \\
\text { Dana pensiun atau } \\
\text { pemanfaatan masa } \\
\text { depan }\end{array}$ & $\begin{array}{l}\text { Dana Cadangan Kuwait } \\
\text { Dana Stabiliasai Minyak Meksiko } \\
\text { Dana kesejahteraan nasional } \\
\text { Rusia, } \\
\text { Norwegia mengatur dana pensiun } \\
\text { global }\end{array}$ & $\begin{array}{l}\text { Dana masa depan } \\
\text { Australia, dana } \\
\text { super Selandia } \\
\text { Baru }\end{array}$ & \\
\hline $\begin{array}{l}\text { Manajemen } \\
\text { Kepemilikan } \\
\text { Pemerintah }\end{array}$ & $\begin{array}{l}\text { Perusahaan Investasi Oman, } \\
\text { Mubadala (UEA) }\end{array}$ & $\begin{array}{l}\text { Temasek } \\
\text { (Singapura), } \\
\text { Khazanah } \\
\text { (Malaysia) }\end{array}$ & $\begin{array}{l}\text { Kepemilikan bank China } \\
\text { dikelola oleh perusahaan } \\
\text { investasi Cina }\end{array}$ \\
\hline $\begin{array}{l}\text { Kekayaan atau } \\
\text { optimalisasi } \\
\text { risiko/pengembalian }\end{array}$ & $\begin{array}{l}\text { Dana cadangan negara Oman, } \\
\text { Otoritas investasi Abu Dhabi } \\
\text { (ADIA) }\end{array}$ & $\begin{array}{l}\text { Govt Investment } \\
\text { Corporation } \\
\text { (Singapura) }\end{array}$ & $\begin{array}{l}\text { Cadangan Devisa Singapura } \\
\text { dikelola oleh co investasi } \\
\text { pemerintah atau cadangan } \\
\text { devisa Korea oleh perusahaan } \\
\text { investasi Korea }\end{array}$ \\
\hline
\end{tabular}

Sumber: (Al-Saidi, 2012) 


\section{METODE}

Metodologi dalam kajian ini menggunakan metode kajian literatur (Library Research) dengan pendekatan komparatif. Studi kepustakaan merupakan suatu studi yang digunakan dalam mengumpulkan informasi dan data dengan bantuan berbagai macam material yang adai di perpustakaan seperti dokumen, buku, majalah, kisah-kisah sejarah, dan sebagainya (Timotius, 2017). Pendekatan komparatif disini digunakan untuk membandingkan suatu kebijakan pada suatu negara, tujuan dari penelitian komparasi yang lebih untuk menyelidiki kemungkinan adanya hubungan sebab akibat dan mencari faktor yang memungkinkan menjadi penyebab melalui data tertentu. Pendekatan komparatif ini akan digunakan secara implisit maupun eksplisit dalam kebijakan pendapatan negara satu dengan lainnya (Djuwita, 2014).

Metode penelitian kepustakaan ini digunakan untuk Menyusun konsep terkait dengan $S W F$ yang nantinya menjadi pijakan kebijakan yang dapat diterapkan di Indonesia, untuk mendapatkan gambaran keberhasilan penerapan $S W F$, kita memerlukan studi komparasi pada kebijakan $S W F$ di Negera Oman. Langkah-langkah dalam penelitian kepustakaan menurut (Kuhlthau et al., 2011) adalah sebagai berikut: a) Pemilihan topik, b) Eksplorasi fokus penelitian, c) Menentukan fokus penelitian, d) Pengumpulan sumber data, e) Persiapan penyajian data, dan f) Penyusunan laporan.

Sedangkan pada penelitian studi komparatif, Langkah-langkahnya menurut (Djuwita, 2014) adalah sebagai berikut: a) Mendefinisikan masalah, b) Melakukan penelaahan kepustakaan, c) Merancang cara pendekatannya dengan memilih subjek-subjek yang akan digunakan serta sumber-sumber yang relevan, memilih atau Menyusun Teknik yang akan digunakan untuk mengumpulkan data, dan menentukan kategori-kategori untuk mengklasifikasikan data yang jelas, sesuai dengan tujuan studi, dan dapat menunjukan kesamaan atau saling berhubungan, d) Memvalidasi Teknik untuk mengumpulkan data itu dan menginterpretasikan hasilnya dengan cara yang jelas dan cermat, e) Mengumpulkan dan menganalisis data, dan f) Penyusunan laporan.

Sumber data menjadi bahan dari penelitian ini berupa buku, jurnal, situs internet yang terkait dengan topik terpilih. Sumber data penelitian ini terdiri dari 5 buku dan 10 jurnal tentang penerapan SWF di negara Oman maupun teks book SWFs.

Pada Teknik pengumpulan data, penelitian ini menggunakan instrument dokumentasi, yaitu mencari data mengenai hal-hal atau variable yang berupa catatan, buku, makalah atau artikel, jurnal dan sebagainya (Arikunto, 2010). Instrument penelitiannya berupa daftar check list klasifikasi bahan penelitian, skema/peta penulisan dan format catatan penelitian.

Untuk dapat melakukan kolaborasi studi kepustakaan dengan studi komparasi, maka Teknik pengumpulan datanya pun kami kolaborasikan. Namun penulis lebih banyak pada penggunaan Teknik studi kepustakaan untuk menganalisis model komparasi penerapan $S W F$ pada negara Oman dengan Indonesia. Karena Indonesia belum menerapkan $S W F$ dalam kebijakan ekonominya, jadi kami melakukan analisis dari sisi strategi penerapan kebijakan $S W F$ karena kebijakan $S W F$ ini belum resmi digunakan.

Teknik analisis data yang digunakan dalam penelitian ini adalah metode analisis isi (Content Analysis). Analisis model ini digunakan untuk mendapatkan inferensi yang valid dan dapat diteliti ulang berdasarkan konteksnya (Krippendorff, 1993). Pada analisis ini penekanannya pada proses memilih, membandingkan, menggabungkan dan memilah berbagai pengertian hingga ditemukan informasi yang relevan (Fitrah, 2018). Untuk menjaga proses pengkajian dan mencegah salah persepsi (kesalahan pengertian manusiawi yang bisa terjadi karena kekurangan penulis Pustaka) maka dilakukan pengecekan antar Pustaka (Sutanto, 2005). 
Teknik Analisa pada pendekatan komparasi dapat melakukan Analisa non hipotesis, yaitu dengan cara peneliti mengadakan komparasi status fenomena dengan standarnya. Karena pada penelitian ini tidak menggunakan hipotesis, maka Langkah-langkah analisis data pada penelitian ini adalah (a) persiapan, (b) mentabulasi data, dan (c) penerapan data sesuai dengan pendekatan penelitian.

\section{HASIL DAN PEMBAHASAN}

\section{Penerapan Kebijakan Sovereign Wealth Funds (SWFs) di Negara Oman}

Seiring dengan kekuatan eksternal seperti persaingan, hukum dan perdagangan, faktor-faktor lain dalam negara seperti kebijakan, hukum dan pola pikir penduduk untuk bisnis, perdagangan dan ekonomi dengan kepercayaan agama dan budaya memiliki penekanan lebih besar pada pertumbuhan negara. Faktor-faktor ini dapat dikategorikan sebagai internal negara dan bersifat kualitatif sebagai sulit diukur secara kuantitas. Pemerintah di seluruh dunia menyiapkan anggaran fiskal dan mengumumkan rencana peningkatan dalam berbagai skema, visi, dan serangkaian reformasi yang biasanya dilaksanakan melalui perubahan perencanaan dan administrasi.

Krisis dan resesi kredit baru-baru ini menunjukkan bahwa perencanaan, evaluasi dan pengendalian untuk transaksi investasi adalah alat yang diperlukan untuk mengendalikan krisis seperti itu lebih lanjut. Di banyak negara di kawasan Timur Tengah dan GCC, pemerintah adalah perusahaan terbesar dan sangat bergantung pada tenaga kerja asing sebagai kekurangan tenaga kerja lokal. Juga, ada kekurangan investasi dari bisnis swasta untuk menjadi pengusaha utama. Dengan demikian, kebijakan pemerintah dan pengaruhnya langsung pada manajemen $S W F$ memiliki dampak besar pada pertumbuhan $S W F$.

$S W F$ dianalisis secara selektif dengan cara membandingkan berbagai atribut yang dimiliki dan setiap permasalahan dalam penelitian. Misalnya, struktur organisasi, proses pengambilan keputusan, strategi investasi, kontrol manajemen, tata kelola, alokasi dan kesepakatan aset, hak dan peraturan investasi, tujuan dan perspektif pengaturan dana ini. Kedua dana kasus akan dianalisis berdasarkan faktor-faktor yang disebutkan dalam proposisi teoritis yang akan menghasilkan perbandingan antara proposisi berdasarkan teori dan praktik industri yang diikuti oleh SWFs. Ini akan membantu dalam mengembangkan prosedur implementasi untuk rencana aksi yang direkomendasikan dalam Oman $S W F$ (Ju et al., 2009).

Tujuan utama dari bagian ini adalah untuk melaksanakan strategi penelitian sebagaimana disebutkan dalam bagian metodologi dengan melakukan pengumpulan data sekunder dan menafsirkan temuan analisis data yang diperoleh berdasarkan pada kedua kasus pendanaan. Bagian dari tesis ini menjadi bagian integral dari proses deduksi untuk menguji proposisi teoritis seperti yang dijelaskan dalam metodologi (Neuman \& Celano, 2006). Ini memfasilitasi untuk menemukan jawaban atas masalah penelitian dan masalah yang didefinisikan dalam pendahuluan pada artikel ini. Masalah-masalah penelitian ini terkait dengan konstruk mendefinisikan variabel yang membentuk proposisi teoritis. Oleh karena itu, diskusi dan jawaban untuk masalah penelitian ini mendukung $S W F$ berfungsi secara keseluruhan. Temuan dari data sekunder dalam bagian ini dapat menghasilkan pandangan yang berbeda tentang berbagai komponen SWF yang dapat membantu peninjauan SWF sebagai sebuah fenomena (Eisenhardt, 1989).

Negara Oman terletak di wilayah Teluk yang memiliki kepentingan strategis dalam perdagangan internasional dan regional sejak lama dan telah memperoleh 
posisi dominan di Dewan Kerjasama Teluk (GCC). Sumber daya alam yang besar dari minyak dan gas, warisan budaya yang telah lama berdiri dan ikatan politik yang baik dengan negara-negara di seluruh dunia telah mendapatkan tempat penting dalam perdagangan, keuangan, dan ekonomi global untuk Oman. Pemerintahan negara yang damai dan stabil sejak tahun 1970 dan seterusnya oleh Sultan Qaboos bersama dengan upaya pembangunan dan pendekatan liberalisasi yang cermat oleh Oman telah menciptakan tempat yang mengagumkan bagi Oman dalam GCC dan politik global. Oman jelas diposisikan dengan baik dengan perkembangan saat ini, proses transformasi ekonomi dan terobosan-terobosan besar seperti Perjanjian Perdagangan Bebas (FTA) dengan AS diimplementasikan mulai Januari 2009. Oman memiliki salah satu pengakuan tertinggi di kawasan ini dengan mencetak peringkat 25 pada indeks perdamaian global, ke-41 di indeks transparansi keseluruhan dan ke-57 dalam iklim bisnis oleh Bank Dunia pada 2008 (The Report: Oman 2009).

Pemerintah Oman dalam rencana pembangunan ketujuh lima tahun, telah menciptakan visi strategis jangka panjang untuk tahun 1995 hingga 2020. Implementasi program privatisasi baru-baru ini telah menyebabkan lonjakan pertumbuhan dalam investasi lokal dan asing di sektor industri seperti listrik dan air. Tujuan rencana tersebut termasuk meningkatkan dan mempercepat transformasi ekonomi dengan meningkatkan fokus pada produksi gas alam, pengembangan industri pariwisata, ekspor non-minyak, pengembangan modal manusia, perluasan sektor informasi, komunikasi dan teknologi (TIK) sambil meningkatkan keseluruhan negara infrastruktur.

Penciptaan kekayaan utama atau sumber pendapatan negara masih dari sumber daya minyak dan gas alam, yakni minyak dan gas bumi, menyumbang lebih dari 90\% dari total ekspor barang dan jasa Oman. Untuk memberikan perlindungan terhadap harga minyak yang rendah di pasar dunia, Pemerintah. Oman adalah salah satu negara pertama di kawasan ini yang mendirikan dana cadangan umum negara $(S G R F)$ yang juga dikenal sebagai dana stabilisasi umum negara (OGSF) pada tahun 1980. Ini adalah titik awal Sovereign Wealth Funds (SWF) Oman pada tahun 1980 yang sekarang terdiri dari empat dana berbeda: dana cadangan negara, dana minyak bumi, dana infrastruktur nasional dan dana lain dimulai pada tahun 2006 dinamakan sebagai Dana Investasi Oman (www.SWFinstitute.org, 2011). Keempat dana ini berada di bawah manajemen langsung Departemen Keuangan sedangkan sembilan dana pensiun lainnya yang hanya memiliki izin investasi dalam negeri dikelola oleh masing-masing departemen fungsional. Misalnya, selama harga minyak tinggi pada 2008, kira-kira. US \$150 per barel, SWF Oman menambahkan US \$2,2 miliar ke dana cadangan minyak yang diperkirakan memiliki aset dalam kisaran US \$ 8,2 miliar hingga 13 miliar pada September 2007. Sejak itu, penciptaan dana cadangan negara, Pemerintah. telah menciptakan dua belas lebih banyak dana seperti yang dijelaskan di atas untuk melindungi anggaran dan untuk mendiversifikasi investasi untuk pertumbuhan jangka panjang dan untuk menghadapi implikasi keuangan di masa depan di negara tersebut (The Report OMAN, 2009). Beberapa langkah privatisasi baru-baru ini seperti restrukturisasi transmisi tenaga, layanan pos dan sektor pengelolaan limbah padat sedang dalam proses. Ini akan meningkatkan persaingan bagi perusahaan lokal untuk tumbuh, untuk meningkatkan ketersediaan layanan yang lebih efektif dan efisien, investasi asing langsung dan membebaskan keuangan negara untuk proyek-proyek penting dan pembangunan lainnya. Pertumbuhan PDB 5\% hingga 6\% telah dipertahankan dalam lima tahun terakhir seperti yang dilaporkan oleh Bank Sentral Oman. Oman telah membuktikan cadangan minyak bumi sekitar 4 miliar barel. Ini 
adalah sumber yang terbatas dan oleh karena itu pemerintah Oman bertujuan untuk mengubah posisi ekonomi yang bergantung pada minyak menjadi ekonomi multichanneled dan non-minyak seperti negara-negara berkembang dan negara-negara industri di seluruh dunia. Pemerintah Oman bertujuan agar negara itu menjadi eksportir utama dengan penekanan khusus pada industri manufaktur.

Oleh karena itu, tujuan strategis untuk mencapai keseimbangan ekonomi dan pertumbuhan yang berkelanjutan tergantung pada pengembangan sumber daya manusia, diversifikasi ekonomi dan pengembangan sektor swasta sebagaimana tercantum dalam visi untuk Oman 2020. Namun, kebijakan saat ini memiliki hambatan yang melekat pada pertumbuhan yang dibuktikan dengan pertumbuhan yang lambat dari tiga dekade terakhir SWF Oman dibandingkan dengan negara-negara anggota GCC lainnya yang $S W F$ nya telah tumbuh lebih dari ratusan miliar. Oleh karena itu, tantangan utama bagi Oman dan pemerintahnya adalah Meningkatkan defisit fiskal dalam anggaran umum dan cadangan keuangan menurun, Meningkatkan defisit fiskal dalam anggaran umum dan cadangan keuangan menurun, Cadangan minyak yang terbatas untuk dua dekade ke depan, Menonjolnya peran pemerintah dalam industri lain mengurangi peluang seperti investor swasta dan inovasi melalui peningkatan persaingan, Kurangnya mekanisme pemantauan dan kontrol yang sesuai di sektor keuangan dan lainnya, Integrasi yang lemah antara minyak dan sektor-sektor pendukung lainnya yang mengarah pada hasil berkualitas rendah dibandingkan dengan standar internasional dan tolok ukur industri, Efisiensi rendah dan pemanfaatan sumber daya yang tersedia tidak efektif, Efisiensi rendah dan pemanfaatan sumber daya yang tersedia tidak efektif, Kurang penting bagi pengembangan sumber daya manusia dan sedikit profesi, dan Ketidakmampuan tenaga kerja lokal untuk menyesuaikan permintaan global dengan kemajuan teknologi.

Di satu sisi, pendirian dan keberhasilan menjalankan dana kekayaan negara tampaknya menjadi solusi yang menjanjikan bagi Oman. Di sisi lain, dana kekayaan ini mengambil input dari pendapatan minyak. Oleh karena itu, harga minyak di pasar global dan cadangan minyak dengan Oman memainkan peran penting dalam pencapaian Visi 2020 untuk Oman. Dampak pada pendapatan SWF dari pendapatan minyak dapat memiliki efek yang diperbesar. Sebagai contoh, hanya satu kejutan deviasi standar dalam harga minyak dapat membuat penurunan pendapatan menjadi 6\% dari PDB ketika pendapatan minyak hanya 20\% dari PDB (Devlin dan Titman 2004; Mitchell, et al 2008). Dari statistik ini, orang dapat menyimpulkan efek turbulensi dari harga minyak ke Oman dan $S W F$-nya di mana pendapatan minyak lebih dari 90\% dari PDB mereka. Negara-negara seperti Chili dan Venezuela telah merancang dana mereka untuk mengimbangi fluktuasi harga semacam itu. Kadang, selama harga minyak rendah, pemerintah ini mungkin harus menutup investasi $S W F$ yang dilakukan selama harga minyak tinggi jika bisnis tidak berkinerja baik. Ini lebih mahal daripada melakukan investasi yang salah. Ini lagi menjadi masalah utama bagi para pengambil keputusan di pemerintahan dan bisnis. Untuk mengurangi efek seperti itu, SWF harus memiliki strategi investasi yang tepat, investasi yang menguntungkan, dan aliran dana yang stabil (Devlin \& Titman, 2004).

Untuk negara seperti Oman, pengembalian yang menguntungkan, pertumbuhan dan stabilisasi mata uang sangat penting untuk dampak langsung terhadap ekonomi dan kehidupan penduduk mereka (Swensen, 2009). Misalnya, jika SWF kecil dibandingkan dengan negara lain dan masih merupakan sumber tunggal terbesar untuk menyeimbangkan sistem keuangan, maka ia memiliki dua masalah utama: mengelola stabilitas dana dan mempertahankan profil rendah tanpa mengungkapkan 
informasi strategis tanpa dana besar mengikuti pimpinan. Ini persis seperti SWF Oman. Ini membuat orang berpikir tentang mekanisme operasi pengambilan keputusan dan manajemen keseluruhan dalam $S W F$. Oleh karena itu, tantangan-tantangan praktis ini mengungkapkan pentingnya $S W F$ bagi ekonomi Oman. Salah satu upaya tersebut dilakukan dalam tesis ini dengan menganalisis $S W F$ Oman dibandingkan dengan $S W F$ lain yang berkembang dengan baik dan menguntungkan.

Kesultanan Oman meluncurkan State Geneal Reserve Fund (SGRF) atau Dana Cadangan Umum Negara ini pada tahun 1980 dengan keputusan Royal untuk mengelola kekayaan negara dari pendapatan minyak, pengembalian dari investasi dan cadangan devisa Kesultanan Oman. SGRF dimiliki oleh Kesultanan Oman dan dikelola oleh Kementerian Keuangan Oman. Sumber moneter SGRF adalah cadangan devisa dari pendapatan ekspor migas dan aset lancar bernilai sekitar US \$ 8,2 miliar hingga 13 miliar. Manajemen operasional SGRF dikelola oleh Kementerian Keuangan (Kemenkeu). Tidak ada mekanisme pengaturan yang diterapkan oleh Kemenkeu dan tidak ada informasi yang diketahui oleh departemen pemerintah lainnya.

Masalah utama dalam mengumpulkan data sekunder adalah bahwa SGRF memiliki transparansi dan tingkat pengungkapan yang sangat rendah. Ini tidak menghasilkan informasi tentang Oman $S W F$ dalam domain publik seperti tidak ada laporan apa pun yang dipublikasikan. Oman SWF (SGRF) tidak dipantau oleh departemen pemerintah mana pun kecuali Kementerian Keuangan. Ini diketahui dari diskusi awal dengan karyawan Oman SWF. Upaya itu dilakukan untuk mendapatkan sebanyak mungkin informasi terkait SGRF dari laporan departemen pemerintah lainnya seperti Bank Sentral Oman (CBO). Atribut berikut menjelaskan status SGRF saat ini, strategi dan operasinya.

Pemerintah Oman belum menerapkan kerangka kerja manajemen atau peraturan dalam tindakan dana kekayaan mereka. Tanggung jawab formal manajemen SGRF berada di tangan Kementerian Keuangan (selanjutnya disebut Kemenkeu) di mana keputusan diambil oleh wewenang diskresi Menteri Keuangan. Dana masuk dan keluar dikelola oleh Bank Sentral Oman (CBO). Namun, SGRF tidak diperlakukan sebagai entitas terpisah seperti dalam kasus Norwegia. SGRF memiliki kurang dari 100 karyawan. Para karyawan ini bekerja untuk Kementerian Keuangan dan mereka tidak dilatih untuk mengelola $S W F$, transaksi atau operasinya, investasi. Tidak ada perjanjian tertulis mengenai peran bersama Kemenkeu dan KSM namun mereka secara bersamasama bertanggung jawab untuk mengelola $S W F$.

Pemerintah Oman belum menerapkan kerangka kerja manajemen atau peraturan dalam tindakan dana kekayaan mereka. Tanggung jawab formal manajemen SGRF berada di tangan Kementerian Keuangan (selanjutnya disebut Kemenkeu) di mana keputusan diambil oleh wewenang diskresi Menteri Keuangan. Dana masuk dan keluar dikelola oleh Bank Sentral Oman (CBO). Namun, SGRF tidak diperlakukan sebagai entitas terpisah seperti dalam kasus Norwegia. SGRF memiliki kurang dari 100 karyawan. Para karyawan ini bekerja untuk Kementerian Keuangan dan mereka tidak dilatih untuk mengelola $S W F$, transaksi atau operasinya, investasi. Tidak ada perjanjian tertulis mengenai peran bersama Kemenkeu dan KSM namun mereka secara bersamasama bertanggung jawab untuk mengelola $S W F$.

Tujuan dan strategi utama SGRF tidak jelas tetapi tujuannya adalah untuk memanfaatkan pendapatan dari hasil pendapatan minyak, gas dan produk minyak bumi. Dengan demikian, adalah tanggung jawab Kemenkeu dan KSM untuk memastikan peningkatan dan keuntungan dari investasi yang dilakukan. Penghasilan dari SGRF harus mencapai populasi Oman. Diagram berikut menunjukkan struktur 
hubungan tanggal antara Pemerintah Oman, departemen Kementerian dan Bank Sentral Oman.

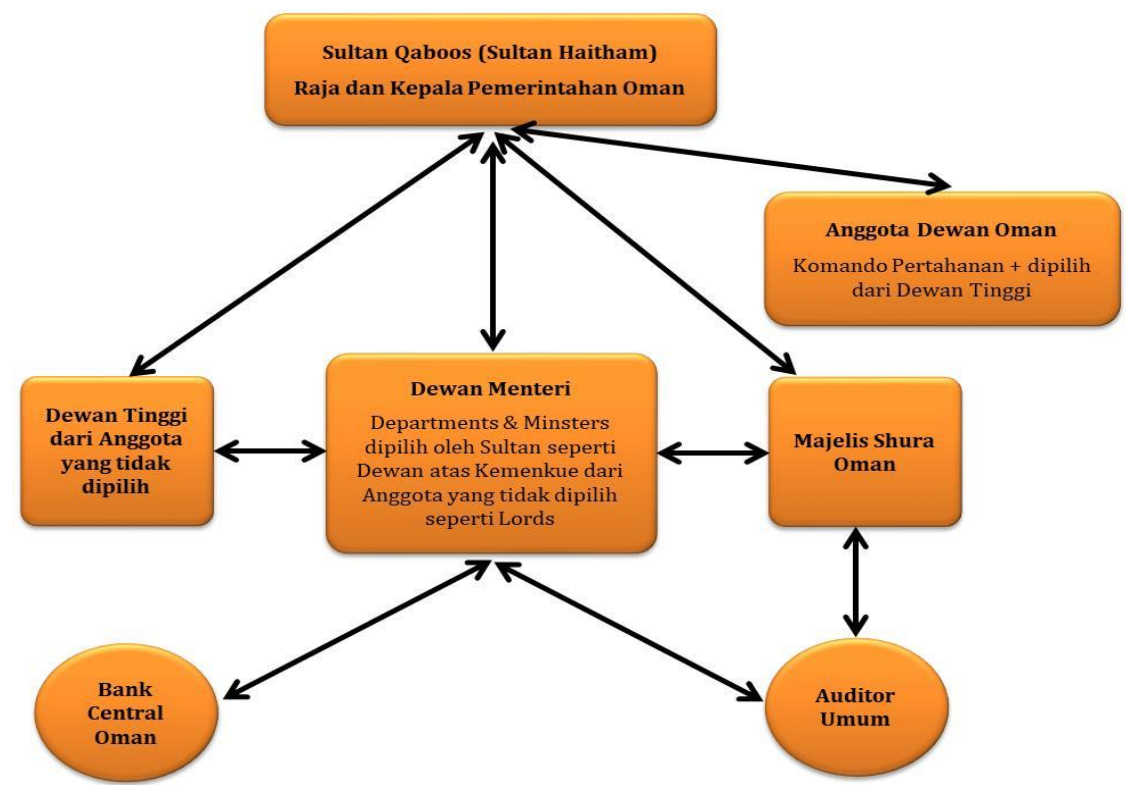

Gambar 1. Tampilan Keberadaan Organisasi $S W F$ dengan Kerjasamanya Adaptasi dari Bank Central Oman (CBO) (The Report: Oman 2009, 2000)

Sebagai bukti dari struktur organisasi, bentuk SGRF saat ini adalah salah satu portofolio menteri dalam Pemerintah. dari Oman. Menurut undang-undang, Kemenkeu seharusnya melaporkan rincian SGRF kepada Auditor General, Bank Sentral Oman, dewan tinggi dan Syura - parlemen seperti yang ditunjukkan di atas dalam diagram; namun Kemenkeu tidak melaporkan rincian SGRF kepada pemangku kepentingan ini. Oleh karena itu dalam kasus SWF Oman.

SGRF mendapat dukungan penuh dari Pemerintah Oman dan Sultan namun tidak ada mekanisme kontrol manajemen di tempat itu. Satu-satunya komponen strategi investasi yang diterapkan oleh SGRF adalah batas arus masuk dana dari pendapatan minyak yang saat ini $15 \%$. Batas tersebut dapat dinaikkan ketika harga minyak tinggi yang memungkinkan ekspansi basis aset, penciptaan portofolio, dan pengembalian yang meningkat. Fundamental lainnya seperti penilaian investasi, alokasi aset, pengukuran dan tolok ukur kinerja SGRF hilang dari kebijakan Kementerian Keuangan saat ini. Dengan demikian, manajemen saat ini dan strategi investasi memerlukan \$ transformasional dan perubahan strategis di Oman SWF (AlSaidi, 2012).

Sebagaimana terbukti dari pembahasan gaya manajemen di atas dan strategi investasi yang sangat lemah - tidak terencana, mudah untuk menyimpulkan bahwa keterampilan karyawan tidak digunakan untuk menumbuhkan dana. Selain itu, Kementerian Keuangan tidak mengizinkan departemen atau dewan lain mana pun memiliki masukan dalam mengelola SGRF. Departemen pemerintah lainnya dan manajemen puncak $S W F$ tidak memiliki informasi terkini dan akurat tentang apa yang terjadi di Oman $S W F$. Tidak ada laporan yang dipublikasikan di domain publik juga. Dengan demikian, tata kelola dan transparansi hampir tidak ada dalam manajemen $S W F$ Oman. Tidak ada karyawan atau pengambil keputusan yang bertanggung jawab jika Oman SWF membuat kerugian dalam kesepakatan investasi. Dengan demikian, profitabilitas adalah masalah serius bagi SGRF. 


\section{Strategi Penerapan Kebijakan Sovereign Wealth Funds (SWFs) di Indonesia}

Cikal bakal pembentukan $S W F$ di Indonesia sebenarnya sudah digagas cukup lama, pemerintah melalui Kementerian Keuangan telah membentuk Pusat Investasi Pemerintah (PIP) yang digadang-gadang untuk menjadi SWF-nya Indonesia berdasarkan Peraturan Menteri Keuangan Nomor 52/PMK.02/2007. Konsep PIP sendiri sebenarnya mengacu pada model $S W F$ yang dimiliki oleh Singapura yaitu Government Investmen Center (GIC) dan Temasek Holding (BUMN Singapura) juga model BUMN Malaysia atau Khazanah Nasional.

Terkait dengan PIP sendiri, diawal pendiriannya mendapatkan suntikan modal Rp 4 triliun, namun dalam perjalanannya investasi yang dikelolanya tidak berkembang sebagaimana harapan pemerintah, yang akhirnya pada tahun 2015 PIP di likuidasi berdasarkan Peraturan Menteri Keuangan Nomor 232/PMK.06/2015. Aset-aset yang dimiliki oleh PIP ini akhirnya dialihkan kepada PT Sarana Multi Infrastruktur (SMI) yang dijadikan bank infrastruktur. Asset tersebut berupa kas dan investasi langsung. Kas tersebut meliputi dana tunai investasi, dana geothermal, dan dana lain yang dikelola PIP sebelumnya.

Sebagaimana kita ketahui, bahwa pada awal tahun 1970 pemerintah Singapura memindahkan kepemilikan Departemen Keuangan ke Temasek yang merupakan $S W F$ nya Singapura. Kemudian diikuti oleh departemen lain yang mentransfer seluruh asset mereka ke dalam kepemilikan khusus sektor besar seperti ShengLi Holding (industry pertahanan) dan Kementerian Pembangunan Nasional (pengembangan perumahan dan korporasi pertanahan) yang seluruh asetnya digabungkan keadalam portfolio Temasek pada awal tahun 1980.

Suatu saat reformasi sektor public akan menjadi penarik yang kuat untuk penciptaan $S W F$ pada pendanaan non-karbon. Sejumlah negara seperti Kahzakhtan, China, Oman, dan Arab Saudi telah melakukan niat mereka untuk mempertimbangkan reformasi perusahaan negaranya seperti yang Singapura lakukan pada Temasek. Sehingga di era meningkatnya defisit anggaran dan kebutuhan untuk mereformasi sector-sektor BUMN yang besar kandidat potensial seperti Indonesia tentu akan mengikuti menerapkan $S W F$ pada pengelolaan kekayaan negaranya.

Tabel 2. Negara yang memiliki rencana merestrukturisasi BUMN

\begin{tabular}{llllcc}
\hline Negara & \multicolumn{1}{c}{ Sektor/Industri } & $\begin{array}{c}\text { Entitas } \\
\text { Potensial yang } \\
\text { Terlibat }\end{array}$ & $\begin{array}{c}\text { Alasan } \\
\text { Restrukturisasi }\end{array}$ & $\begin{array}{c}\text { Pertimb } \\
\text { angan } \\
\text { SWF }\end{array}$ & Role Model \\
\hline Tiongkok & $\begin{array}{l}\text { Logistic, energy, } \\
\text { industry, Telkom }\end{array}$ & $\begin{array}{l}\text { BUMN dibawah } \\
\text { SASAC }\end{array}$ & $\begin{array}{l}\text { Kombinasi fiscal dan } \\
\text { tekanan efisiensi, } \\
\text { pengenalan } \\
\text { ketertiban pasar }\end{array}$ & Ya & $\begin{array}{l}\text { Temasek } \\
\text { (Singapura) }\end{array}$ \\
$\begin{array}{l}\text { Saudi } \\
\text { Arabia }\end{array}$ & Energy & Aramco & Diversifikasi & Ya & Temasek \\
(Singapura)
\end{tabular}

Sumber: (Bernstein et al., 2013) diolah

Berdasarkan tabel diatas, Indonesia mempunyai 199 BUMN besar termasuk PT. Pertamina yang dapat direstrukturisasi dan efisiensi untuk menjalankan SWF-nya, kita bisa melihat model Malaysia dengan BUMN Khazanah Nasionalnya yang melakukan 
ekspansi bisnisnya keluar negeri setelah melakukan restrukturisasi dan efisiensi dalam perusahaannya. Beberapa negara lain seperti Tiongkok, Saudi Arabia, bahkan Oman yang sudah menerapkan SWF juga telah merencanakan untuk resktrukturisasi pada BUMNnya masing-masing.

Perbedaan prioritas utama antara $S W F$ ini adalah apa yang dibutuhkan Oman adalah untuk menciptakan strategi investasi dasar dan kerangka kerja tata kelola untuk mencapai tujuan dana lebih lanjut sedangkan SWF pada kasus di Indonesia menghitung keseluruhan investasi dasar dan kemudian dibentuk kerangka kerja tata Kelola untuk dapat mengelola investasi tersebut. Meskipun Oman bukanlah contoh sempurna untuk penerapan $S W F$ di Indonesia, namun kita dapat mengambil konsep $S W F$ yang ada pada negara Oman untuk dijadikan pijakan strategi $S W F$ terutama pada pengelolaan cadangan minyak bumi dan mineral lainnya. Kita dapat membentuk lembaga Satuan Kerja Khusus Mineral dan Batubara (SKK Minerba) untuk menghitung keseluruhan asset mineral dan batu baru yang kita miliki, SKK Minerba ini dapat dijadikan lembaga pengelola dana investasi yang dimiliki pemerintah di bidang mineral dan batubara. Konsep badan pengelola $S W F$ ini juga dapat dikembangkan dalam bentuk lain atau pengelolaan bidang-bidang strategis untuk mengkalkulasi investasi, cadangan devisa, surplus perdagangan dan surplus anggaran, dana hasil privatisasi, dan penerimaan negara dari ekspor sumber daya alam.

Setidaknya ada lima jenis bentuk pengelolaan $S W F$, jika mengacu beberapa negara di dunia yang sudah menerapkan $S W F$ ini dalam pengelolaan kekayaan negaranya diantaranya adalah: 1) Dana stabilisasi (stabilization funds), 2) Dana Tabungan untuk generasi di masa depan (saving or future generation fund), 3) Dana pension (pension reserve fund), 4) Dana cadangan investasi (reserve investment fund), dan 5) Dana pengelola kekayaan negara untuk pembangunan strategis (strategic development wealth fund).

Meskipun secara risiko pengelolaan dana SWF ini cenderung berisiko dibandingkan dengan model cadangan devisa tradisional karena imbal hasil (return) yang diutamakan dibandingkan likuiditas, namun bagi Indonesia $S W F$ akan menjadi diversifikasi terutama bagi sumber pendapatan yang berasal dari mineral dan batubara yang cukup banyak dimiliki oleh Indonesia. Selain belajar dari Oman kita juga dapat meniru konsep yang dimiliki Uni Emirat Arab (UEA) dengan Abu Dhabi Investment Authority yang sekarang tercatat sebagai top 10 SWF di Dunia.

\section{KESIMPULAN}

Selama ini pemerintah Indonesia melakukan kajian untuk penerapan kebijakan $S W F$, namun selama ini model yang diterapkan belum berhasil untuk mengelola dana invastasi maupun cadangan devisa. Sebenarnya potensi Indonesia untuk menerapkan kebijakan $S W F$ ini sangat besar, mengingat kita mempunyai banyak instrument pendukung $S W F$ seperti minyak bumi, mineral jarang, dan batubara atau juga bisa menerapkan sumber dana pensiun sebagaimana yang dilakukan oleh Norwegia dan Jepang dalam melakukan invansi investasinya ke luar negeri. Secara garis besar sebenarnya $S W F$ ini cukup berisiko karena mengandalkan imbal hasil (return) yang cepat dibandingkan likuiditas. Namun justru hal tersebut dapat lebih cepat untuk mengembangkan dana $S W F$ ini dengan instrument penempatan investasi yang produktif.

Harapnya pemerintah lebih cermat dalam penerapan kebijakan $S W F$, harus menghitung lebih detail terkait dengan risiko investasi yang cukup besar. Sehingga penerapan $S W F$ akan lebih terencana dan bisa mewujudkan kesejahteraan social masyarakat Indonesia. 


\section{DAFTAR RUJUKAN}

Al-Saidi, M. (2012). Analytical study of sovereign wealth fund's strategies and policies: A case study of Oman sovereign wealth fund [Brunel University Brunel Business School PhD Theses]. https://bura.brunel.ac.uk/handle/2438/6494

Arikunto, S. (2010). Metode Peneltian. Jakarta: Rineka Cipta.

Bernstein, S., Lerner, J., \& Schoar, A. (2013). The investment strategies of sovereign wealth funds. Journal of Economic Perspectives, 27(2), 219-238. https://doi.org/10.1257/jep.27.2.219

Devlin, J., \& Titman, S. (2004). Managing oil price risk in developing countries. The World Bank Research Observer, 19(1), 119-139. https://www.jstor.org/stable/3986495?seq=1

Dewenter, K. L., Han, X., \& Malatesta, P. H. (2010). Firm values and sovereign wealth fund investments. Journal of Financial Economics, 98(2), 256-278. https://doi.org/10.1016/j.jfineco.2010.05.006

Djuwita, P. (2014). Penelitian KOmparatif [FKIP Universitas Bengkulu]. In FKIP Universitas Bengkulu,. http://pgsdberbagi.blogspot.co.id/2014/01/penelitian-komparatif.html

Eisenhardt, K. M. (1989). Making fast strategic decisions in high-velocity environments. Academy of Management Journal, 32(3), 543-576. https://doi.org/10.2307/256434

Fitrah, M. (2018). Metodologi penelitian: penelitian kualitatif, tindakan kelas \& studi kasus. CV Jejak (Jejak Publisher).

Ju, X.-T., Xing, G.-X., Chen, X.-P., Zhang, S.-L., Zhang, L.-J., Liu, X.-J., Cui, Z.-L., Yin, B., Christie, P., \& Zhu, Z.-L. (2009). Reducing environmental risk by improving $\mathrm{N}$ management in intensive Chinese agricultural systems. Proceedings of the National Academy of Sciences, 106(9), 3041-3046. https://doi.org/10.1073/pnas.0813417106

Kotter, J., \& Lel, U. (2011). Friends or foes? Target selection decisions of sovereign wealth funds and their consequences. Journal of Financial Economics, 101(2), 360-381. https://doi.org/10.1016/j.jfineco.2011.03.007

Krippendorff, K. (1993). Major metaphors of communication and some constructivist reflections on their use. Cybernetics \& Human Knowing, 2(1), 3-25. https://repository.upenn.edu/asc_papers/84/

Kuhlthau, K. A., Bloom, S., Van Cleave, J., Knapp, A. A., Romm, D., Klatka, K., Homer, C. J., Newacheck, P. W., \& Perrin, J. M. (2011). Evidence for family-centered care for children with special health care needs: a systematic review. Academic Pediatrics, 11(2), 136-143. https://doi.org/10.1016/j.acap.2010.12.014

Mahajan, A., Bhagat, R. M., \& Gupta, R. D. (2008). Integrated nutrient management in sustainable rice-wheat cropping system for food security in India. SAARC Journal of Agriculture, 6(2), 29-32.

Neuman, S. B., \& Celano, D. (2006). The knowledge gap: Implications of leveling the playing field for low-income and middle-income children. Reading Research Quarterly, 41(2), 176-201. https://doi.org/10.1598/RRQ.41.2.2

Sutanto, R. (2005). Dasar-Dasar Ilmu Tanah, Konsep dan Kenyataan. Kanisius.

Swensen, D. F. (2009). Pioneering portfolio management: An unconventional approach to institutional investment, fully revised and updated. Simon and Schuster.

The Report: Oman 2009. (2000). Oxford Business Group.

Timotius, K. H. (2017). Pengantar Metodologi Penelitian: Pendekatan Manajemen Pengetahuan untuk Perkembangan Pengetahuan. Penerbit Andi. 